\title{
Effect of AlsFeSi Phases in Secondary AIZn10Si8Mg Cast Alloys on Mechanical Properties and Fracture Surface
}

Eva Tillová, Mária Chalupová, Denisa Závodská, Lenka Kuchariková, Juraj Belan, Alan Vaško

Faculty of Mechanical Engineering, University of Žilina, Univerzitná 8215/1, 01026 Žilina, Slovak Republic. E-mail: eva.tillova@fstroj.uniza.sk

Effect of brittle plate-like Al5FeSi iron phases in secondary (scrap-based - recycled) AIZn10Si8Mg cast alloys with different amount of iron (0.150 wt. \% and 0.559 wt. \%) on microstructure, mechanical properties (UTS, YTS, ductility and Brinell hardness) and fracture surface were studied. Standard, colour and deep etching were utilized for observation and identification of intermetallic phases (in order to reveal the 3D-morphology of the $\mathrm{Si}$-particles and intermetallic phases). X-ray analysis was used for the evaluation of element composition of the specimen. The results show that SDAS factor decreases with increasing the Fe content; the area proportion and the average length of $\mathrm{Al}_{5} \mathrm{FeSi}$ phases increased; mechanical properties slightly decreased (YTS from 185 MPa to 176 MPa and UTS from $187 \mathrm{MPa}$ to $178 \mathrm{MPa}$ ). The fracture surface consists of transcrystalline ductile fracture, in alloy with 0.150 wt. \% Fe the transcrytalline ductile fracture is dominant in the eutectic and on the $\alpha$-matrix and the transcrystalline cleavage fracture was observed not much; in alloy with $0.559 \mathrm{wt}$. \% Fe the transcrystalline cleavage fracture is dominant.

Keywords: Al-Zn-Si cast alloy, tensile properties, microstructure, iron phases, fracture surface

\section{Introduction}

Aluminum castings are used for various industrial applications, mainly in the automotive industry, including engines, transmissions, wheels, cylinder blocks and heads, pistons, brake cylinders, and suspension arms. The substitution of aluminum casting for ferrous casting in the automotive sector is predicted to increase further as automakers continue to seek opportunities to reduce vehicular weight. The advantages associated with the use of aluminum alloys, such as lighter weight, excellent mechanical behavior, and good corrosion resistance, constitute the driving force for the introduction of new applications and designs and for the development of new processing solutions. Various processes are competing currently to achieve, both economically and technologically, more expedient production of aluminum alloys castings [1].

Aluminium alloys have positive environmental impact. Secondary aluminum production not only uses less energy, it reduces landfill waste, contributes much lower greenhouse gas emissions and greatly reduces costly international transportation. A $10 \%$ increase in aluminum end-of-life recycling rates decreases industry greenhouse gas emissions by $15 \%$. Leading companies such as Apple use recycled aluminum to achieve their aggressive sustainable manufacturing goals while building lightweight and artfully designed end products that delight customers. The company achieved a $66 \%$ recycling rate in 2009 and has set a goal of $70 \%$ for 2015 . Customers are increasingly looking to buy from companies with a strong sense of corporate responsibility and a solid environmental track record. As more companies see the link between sustainable manufacturing, customer loyalty and profits, the interest in recycled aluminum will continue to rise. The aluminum can is often the subject of recycling success stories and statistics, but the recycling rates in the auto and building/construction industries are even higher.
At present, $95 \%$ of aluminium used in automotive industry can be recycled at the end of its operation [2-5].

Commercial secondary (recycled) Al-alloys always contain Fe, often as undesirable impurity and occasionally as a useful minor alloying element. Depending on the quality of the incoming ore and the control of the various processing parameters and other raw materials, molten primary Al-metal typically contains between $0.02-0.15$ wt. \% iron, with average contains $\sim 0.07-0.10 \%[3,6-8]$. Secondary Al-alloys (produced from Al-scrap) contain higher background iron levels than the primary metal. In an amount $0.3-0.5 \mathrm{wt}$ \% of Fe, it prevents sticking casting on the metal mould (for casting under pressure), increases the strength and in larger quantities also the heat resistant. At higher contents, as $0.3-0.5$ wt. \% of Fe, it causes first of all formation of Fe-intermetallic phases [3].

$\alpha-\mathrm{Al}_{15} \mathrm{FeMn}_{3} \mathrm{Si}_{2}$ (with skeleton-like or Chinese script morphology) and $\beta-\mathrm{Al}_{5} \mathrm{FeSi}$ phases (with needle/plate like morphology) are the more important. The $\mathrm{Al}_{5} \mathrm{FeSi}$ phase is mostly associated with greater iron levels, roughly the location of the eutectic trough on the Al-SiFe phase diagram [7-10]. The $\beta-\mathrm{Al}_{5} \mathrm{FeSi}$ phase is considered the most critical among the iron intermetallics, as it significantly reduces the alloy ductility and fracture toughness. Existing in the form of thin and brittle platelets that appear as needles in the microstructure, the size of these $\beta$-platelets or needles is controlled by the iron content and the solidification conditions of the alloy. In comparison, the $\alpha$-iron phase, due to its compact morphology, is less harmful to the mechanical properties [11-13]. Metallographic studies have shown that pores are nucleated along the long sides of the $\beta$-platelets. However, in spite of the harmful effect of these $\mathrm{Al}_{5} \mathrm{FeSi}$-platelets as pore nucleation sites, their presence also appears to limit pore growth. The size and density of Fe-based intermetallic phases are increased with increasing $\%$ of $\mathrm{Fe}$, also the dimensions of the defects and porosity of casting [14-16]. The higher content of $\mathrm{Fe}$ causes a negative influence to 
the strength and the plastic properties, and the corrosion resistant $[11,12,15-16]$. Control of the iron level is thus technically important, especially where the production of critical components is concerned. There are different measures adopted to neutralize the harmful effect of the needle-like Fe-phase: rapid solidification, addition of neutralizers such as $\mathrm{Mn}$, Co and $\mathrm{Cr}$, melt superheat, Srmodification and non-equilibrium solution heat treatment [17-21].

$\mathrm{Al}-\mathrm{Zn}-\mathrm{Si}-\mathrm{Mg}$ cast alloy has been developed in the recent years as a new generation of Al-alloy for automotive industry [22-24]. The present study is a part of larger research project, which was conducted to investigate and to provide better understanding properties of secondary (recycled) Al-Si cast alloys. The main objective of this work was to study the effect of $\mathrm{Al}_{5} \mathrm{FeSi}$ phases on mechanical properties and fracture surface in secondary cast alloys (new self-hardening AlZn10Si8MgMn alloy) with different iron content.

\section{Experiments}

The materials used in experiment were secondary (scrap-based, recycled) AlZn10Si8Mg cast alloys with different percentage of Fe (alloy A - 0.150 and alloy B 0.559 wt. \%). AlZn10Si8Mg is a self-hardening alloy that is particularly used when good strength values are required without the need for heat treatment. Actually, this alloy is tested as a possible replacement for a conventional alloy AlSi7Mg.

Test bars (ø $20 \mathrm{~mm}$ with length $300 \mathrm{~mm}$ ) were produced from AlZn10Si8Mg ingots by process of sand casting in company UNEKO, Zátor, Ltd. Czech Republic. Consequently, specimens for mechanical tests were produced by machining. Sand casting is the simplest and most widely used casting method. The melt was not modified or refined. Chemical composition of alloys determined by spectrometry SPECTROMAX is given in Tab. 1.

Tab. 1 The chemical composition of experimental AlZn10Si8Mg cast alloys in wt. \%

\begin{tabular}{|l|l|l|l|l|l|l|l|}
\hline Alloy & $\mathrm{Si}$ & $\mathrm{Zn}$ & $\mathrm{Fe}$ & $\mathrm{Mg}$ & $\mathrm{Cu}$ & $\mathrm{Ti}$ & $\mathrm{Al}$ \\
\hline $\mathrm{A}$ & 8.64 & 9.60 & 0.150 & 0.452 & 0.005 & 0.0624 & balance \\
\hline $\mathrm{B}$ & 8.83 & 9.30 & 0.559 & 0.319 & 0.008 & 0.0490 & balance \\
\hline
\end{tabular}

In alloys A, B: Ni (0.0022); Bi (0.0003); Sb (0.0007)

The measurement of mechanical properties was obtained after tensile tests on device Instron 5985 at room temperature (according to the standard ISO 6892-1A), where the test results include $\mathrm{R}_{\mathrm{p} 0.2}$ (yield tensile strength - YTS), $\mathrm{R}_{\mathrm{m}}$ (ultimate tensile strength - UTS) and A (elongation). Three test specimens for each series of alloys A, $\mathrm{B}$ were used to determine the mechanical properties. The total length of the test specimens was $150 \mathrm{~mm}$ and the gage length $10 \mathrm{~mm}$, consequently the average value was calculated. The hardness was obtained with the use of device NEXUS 3000. The Brinell hardness test (HBW $5 / 250$ ) was performed using a $5 \mathrm{~mm}$ diameter hard-metal ball pressed with a force of $250 \mathrm{kp}$ for 10 seconds. 5 measurements were done for each sample. Microhardness was obtained with the use of device ZwickRoell. 10 measurements were done for each sample (HV 0.025 in $\alpha$-matrix; HV 0.025 in eutectic).

Samples for metallographic analysis on SEM and for image analysis were chosen from cast specimen after tensile tests. The samples were prepared by standard metallography methods for Al-Si alloys and etched by $0.5 \%$ $\mathrm{HF}$ acid. Deep etching for $30 \mathrm{~s}$ in $\mathrm{HCl}$ acid was used to dissolve the matrix ( $\alpha$-phase) to reveal the 3D morphology of the phases. The microstructure was observed and documented on scanning electron microscope TESCAN VEGA LMU II. Chemical composition of phases was analyzed by X-ray spectroscopy (EDX analyzer Brucker Quantax). Quantitative evaluation of $\mathrm{Al}_{5} \mathrm{FeSi}$ phases (plates or needles as they appear on the sample surface under a microscope) was performed on metallographic samples that were prepared by standard procedures. Evaluation was carried out on a NEOPHOT 32 optical microscope using the NIS Elements 4.20 software.

\section{Results}

Mechanical properties of Al-alloys producers usually indicate only for the primary alloys. Secondary alloys include a higher percentage of alloying addition, and various types of undesirable intermetallic phases, and therefore the study of their structure, properties and optimizing parameters affecting the structure and properties of secondary alloys in order to achieve for comparable mechanical and casting properties of alloys as the primary, is highly progressive.

The microstructures of the alloys with different content of Fe are shown in Fig. 1 and Fig. 2. The microstructures of alloys A and B are the same and consist of $\alpha$ phase, eutectic and variously types of intermetallic phases (Chinese script $-\mathrm{Mg}_{2} \mathrm{Si}$, Fe-needles $-\mathrm{Al}_{5} \mathrm{FeSi}$ and ternary eutectic $\mathrm{Al}-\mathrm{MgZn}_{2}-\mathrm{Cu}$ ). The $\alpha$-matrix precipitates from the liquid as the primary phase in the form of dendrites and is nominally comprised of Al and $\mathrm{Zn}$. Eutectic phase (dark crystals of $\mathrm{Si}$ in $\alpha$-matrix) have been identified as major constituent, silicon particles are like small grains of poorly rounded, thickened grains and were observed on the periphery of $\alpha$-phase dendrites. In alloy A $(0.150 \%$ of $\mathrm{Fe})$ compared to the alloy $\mathrm{B}(0.559 \%$ of $\mathrm{Fe})$ there is visible that eutectic silicon has a slightly coarser structure on the edge in $\alpha$-phase and the $\mathrm{Al}_{5} \mathrm{FeSi}$ needles are shorter and thinner (Fig. 1a, 2a).

The addition of magnesium to alloy AlZn10Si8Mg is intended to increase its mechanical properties as a precipitation hardener. Magnesium in alloy $\mathrm{AlZn} 10 \mathrm{Si} 8 \mathrm{Mg}$ is merging with silicon and form intermetallic phase of the $\mathrm{Mg}_{2} \mathrm{Si}$ (black phases with Chinese schript morphology). The presence of $\mathrm{Zn}$ - based phases (bright white particles in Fig. 1a, 2a) has been detected by SEM observation and 
EDX analysis. Zn has been subjected to a diffusion proces responsible of the self-hardening behaviour of these types of alloys. Self-hardening starts when the castings are removed from the mould. Casting obtained after first day of natural aging approximately $50 \%$ at room temperature, after second and third day approximately $80 \%$ and the diffusion process seems to be stabilized after 8-10 days, no significant differences have been detected after this period (the increase on strength is normally complete). Moreover, the risk of component's deformation is completely eliminated without heat treatment, that can occur during the different steps of heat treatment, and which are the main reason of most of the component's faults [22, 23].

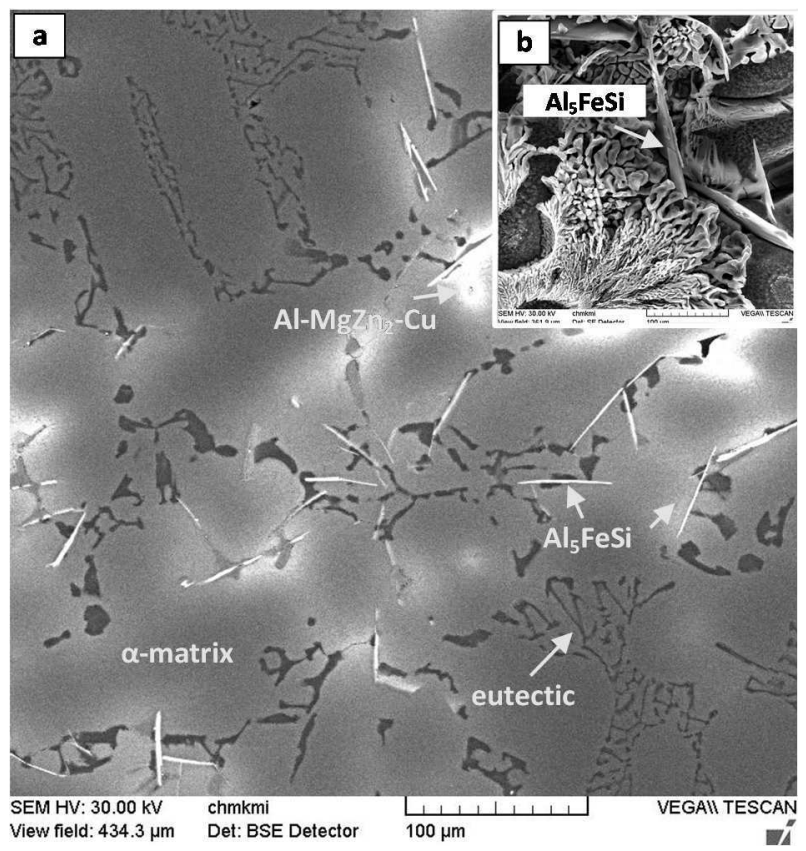

Fig. 1 Microstructure of AlZn10Si8Mg cast alloy with $0.150 \% \mathrm{Fe}:$ a) distribution of $\mathrm{Al}_{5} \mathrm{FeSi}$ needles, etch. 0.5 $\% \mathrm{HF}$; b) morphology of eutectic Si and $\mathrm{Al}_{5} \mathrm{FeSi}$ phases, deep.etch. $\mathrm{HCl}$, SEM

With regard to Taylor [7 8], $\mathrm{Al}_{5} \mathrm{FeSi}$ platelets/needles can grow up to two or more millimetres in slowly cooled $\mathrm{Al}$-Si alloy castings with high $\mathrm{Fe}$ and/or Mn levels. However, under normal casting conditions and moderate $\mathrm{Fe}$ levels, these intermetallics grow more typically in the size range of $50-500 \mu \mathrm{m}$ and in castings with very high cooling rates (e.g. HPDC) and/or when using low wt. \% Fe (e.g. primary alloy ingot), the intermetallic particles are typically of the order of $10-50 \mu \mathrm{m}$. The results of quantification of Fe-phases in experimental alloys are documented in Tab. 2. It was observed that in the alloys A and $\mathrm{B}$; the size, amount and thickness of iron needles are different. Due to increasing the Fe-content it was measured that average length of needles increased from $20.98 \mu \mathrm{m}$ to $27.71 \mu \mathrm{m}$ and needles were observed as thicker ones. The maximum length of needles was increasing from
$69.88 \mu \mathrm{m}$ to $108.62 \mu \mathrm{m}$. Fe-needles long more as $108 \mu \mathrm{m}$ were found sporadically in alloy $\mathrm{B}$, but it can be seen also in works $[7,14]$. The needles were not recorded longer than $400 \mu \mathrm{m}$. The area proportion of $\mathrm{Al}_{5} \mathrm{FeSi}$ phases grows with increasing content of iron from $0.9 \%$ to 2.15 $\%$.

$\mathrm{Al}_{5} \mathrm{FeSi}$ phase is suggested some autors [25] as a possible nucleant for eutectic Si. This argument was mainly based on the observation that $\mathrm{Al}_{5} \mathrm{FeSi}$ phase was often found to coexist or occur in close contact with eutectic Si as it is observed in Fig. 3. But further authors as Dahle and Hillert [26], contend, the $\mathrm{Al}_{5} \mathrm{FeSi}$ phases do not play a major role in the nucleation of the large number of silicon plates that are found in a eutectic colony. This question is very interesting and will be study moreover.

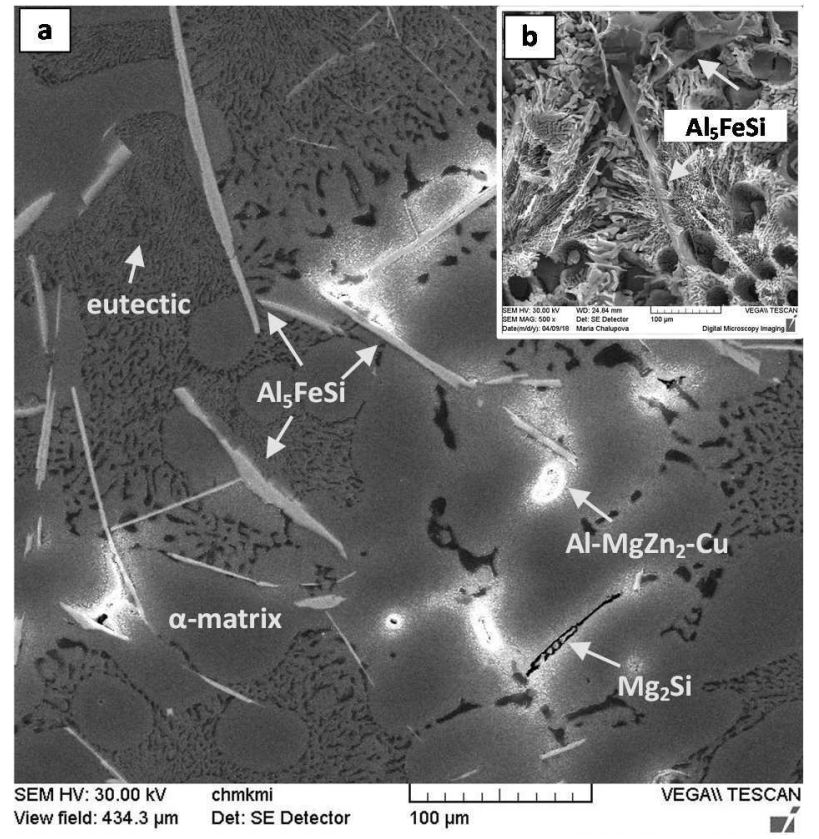

Fig. 2 Microstructure of AlZn10Si8Mg cast alloy with $0.559 \% \mathrm{Fe}:$ a) distribution of $\mathrm{Al}_{5} \mathrm{FeSi}$ needles, etch. 0.5 $\% \mathrm{HF}$; b) morphology of eutectic Si and $\mathrm{Al}_{5} \mathrm{FeSi}$ phases, deep.etch. $\mathrm{HCl}, \mathrm{SEM}$

The cooling rate represents an important parameter which affects SDAS factor (secondary dendrite arm spacing), eutectic Si morphology and dimensions. SDAS was measured $59 \mu \mathrm{m}$ for alloy A and $51 \mu \mathrm{m}$ for alloy B. Taylor [7] and Rosso [23] measured relationship between cooling rate and SDAS factor. SDAS values decrease with increasing cooling rate, because of the higher undercooling and faster movement of solid-liqiud interface. As cooling rate increases, the size of the Si particles became smaller and an important variation of the Si morphology has been observed - fine Si-bars. On castings from alloy $\mathrm{B}$, there were used probably slightly higher cooling rate $(51 \mu \mathrm{m})$ as in castings from alloy A $(59 \mu \mathrm{m})$. Therefore Si particles are finner in alloy B (Fig. 1b, 2b).

Tab. 2 Quantification of $\mathrm{Al}_{5} \mathrm{FeSi}$ phases

\begin{tabular}{|c|c|c|c|}
\hline & the average length of $\mathrm{Al}_{5} \mathrm{FeSi}, \mu \mathrm{m}$ & the maximum length of $\mathrm{Al}_{5} \mathrm{FeSi}, \mu \mathrm{m}$ & the area proportion of $\mathrm{Al}_{5} \mathrm{FeSi}, \%$ \\
\hline $\mathrm{A}$ & $20.98 \pm 2$ & $69.88 \pm 2$ & $0.9 \pm 0.2$ \\
\hline $\mathrm{B}$ & $27.71 \pm 2$ & $108.62 \pm 2$ & $2.15 \pm 0.2$ \\
\hline
\end{tabular}




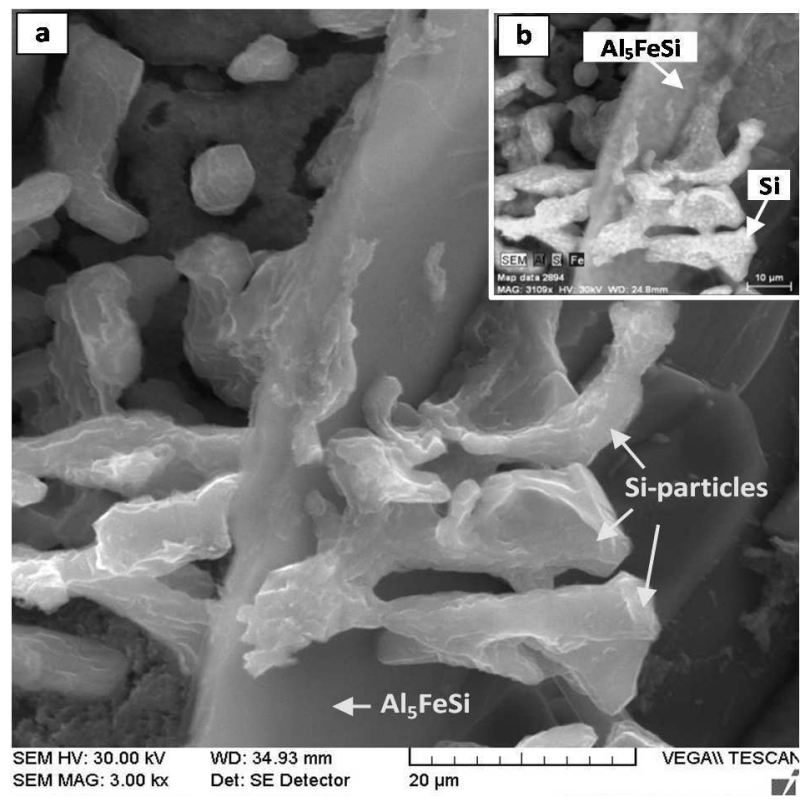

Fig. 3 Morphology of phases: a) Si grows on $\mathrm{Al}_{5} \mathrm{FeSi}$ phase; b) EDX - mapping, deep.etch. $\mathrm{HCl}$, SEM
Results from tensile tests are summarized in Tab. 3 . The mechanical properties of alloy A and alloy B are not very different, but there is a decrease in alloy $\mathrm{B}$ in yield tensile strength (YTS) by $9 \mathrm{MPa}$, it is $5 \%$ decrease and also in ultimate tensile strength decrease by $9 \mathrm{MPa}(5 \%)$ too. Ductility has not changed. The results of Brinell hardness show that the hardness increases with increasing iron content from $83 \mathrm{HBW}$ to $86 \mathrm{HBW}(+3.60 \%)$, probably due to the presence of a higher amount of hard Fephases. Needle-shaped edges and formation of sharp corners of $\mathrm{Al}_{5} \mathrm{FeSi}$ phase reduced maximum yield tensile strength and UTS, but no markedly. Brittle phase cut the matrix and produced stress concentration and thus degrades the mechanical properties (YTS and UTS).

Even though the values of yield tensile strength and ultimate tensile strength in alloy A and alloy B are not different significantly, it can be seen, that character of the fracture surface after tensile tests is different. The fracture surface was influenced very significantly by structural components (eutectic Si, iron phases) and their distribution in the cross-section.

Tab. 3 Mechanical properties of AlZn10Si8Mg (wt. \%) alloys

\begin{tabular}{|c|c|c|c|c|}
\hline & YTS [MPa] & UTS [MPa] & Ductility [\%] & Hardness HBW \\
\hline A & $185 \pm 2$ & $187 \pm 2$ & $2 \pm 1$ & $83 \pm 2$ \\
\hline B & $176 \pm 2$ & $178 \pm 2$ & $2 \pm 1$ & $86 \pm 2$ \\
\hline
\end{tabular}

The typical fractographic surfaces are shown in Fig. 4. Macrographs of the whole fractured surfaces are different. While in matrix of alloy A (Fig. 4a) pores are mainly in the subsurface of the material, in aluminium alloy B (Fig. 4b) they are on surface and in subsurface. The fracture was obtained to initiate micro-voids at the subsurface of the specimen leading to the formation of the local micro-cleavege facets. SEM micrographs of fractured tensile test bars (alloy A, B) have similar pattern of damage.

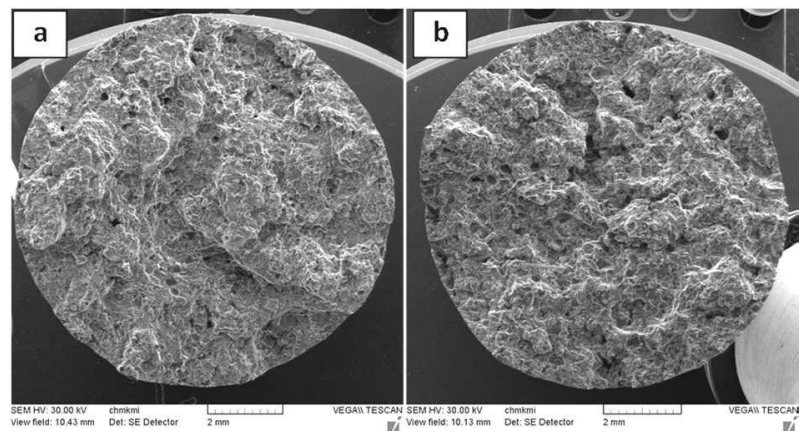

Fig. 4 Macrograph of the whole fractured surfaces: a) alloy $A$; b) alloy $B, S E M$

The fracture surface of experimental samples in alloy A consists of transcrystalline ductile fracture (Fig. 5a). Transcrystalline cleavage fracture (related to the presence of hard and brittle $\mathrm{Al}_{5} \mathrm{FeSi}$ intermetallic phases) was observed not much. The transcrystalline ductile fracture on the eutectic and on the Al-matrix ( $\alpha$-phase) region is dominant (Fig. 5b); because silicon particles have fine bars morphology and Fe- rich intermetallic phases are little and short. The fracture surface was produced by microvoid coalescence and contained dimples of various orientation. The shape and size of the dimples are determined by the size and distribution of eutectic silicon particles (Fig. 5b).

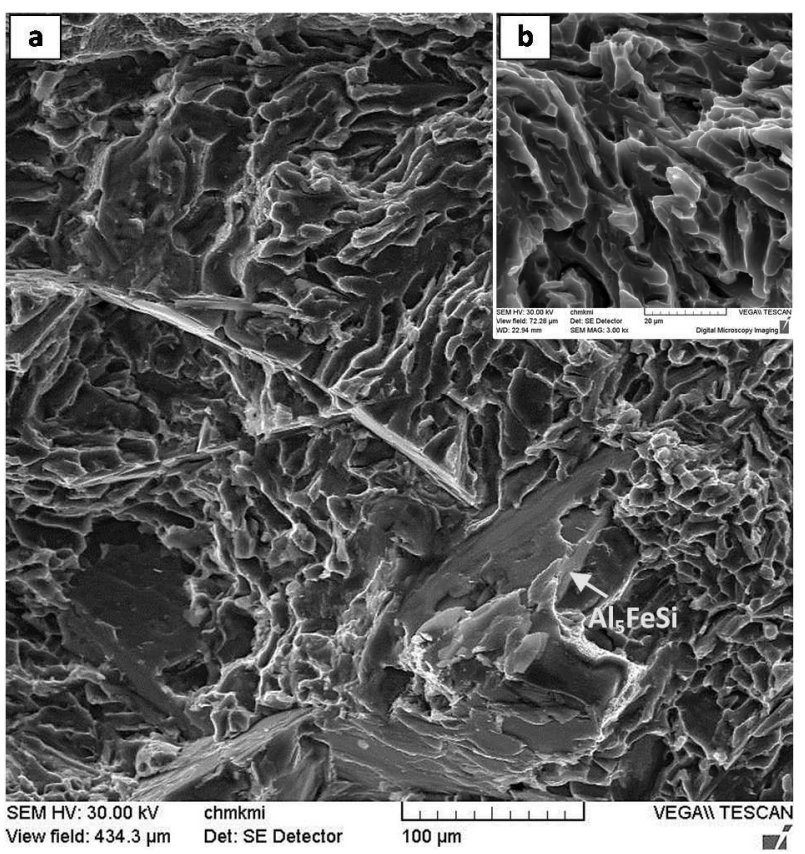

Fig. 5 Fracture surface in alloy with $0.150 \% \mathrm{Fe}$ : a) transcrystalline ductile fracture with cleaved $\mathrm{Al}_{5} \mathrm{FeSi}$ phases; b) detail of ductile fracture of $\alpha$-matrix, SEM

The fracture surface of experimental samples in alloy B consists of transcrystalline cleavage and ductile fracture (Fig. 6a). Transcrystalline cleavage fracture is dominant. Cleavage fracture is related to the presence of larger number of hard and brittle iron intermetallic phases in the structure (Fig. 6b). The transcrystalline ductile fracture of 
Al-matrix ( $\alpha$-phase) is observed in the smaller surface, despite the fact that the Al-Si alloys are breaking exclusively by transcrystalline ductile fracture. The shape and size of the dimples in alloy B are determined by the size and distribution of eutectic silicon particles, too.



Fig. 6 Fracture surface in alloy with $0.559 \% \mathrm{Fe}$ : a) transcrystalline cleavage and ductile fracture; b) detail of river marks in fracture of $\mathrm{Al}_{5} \mathrm{FeSi}$ phase, SEM

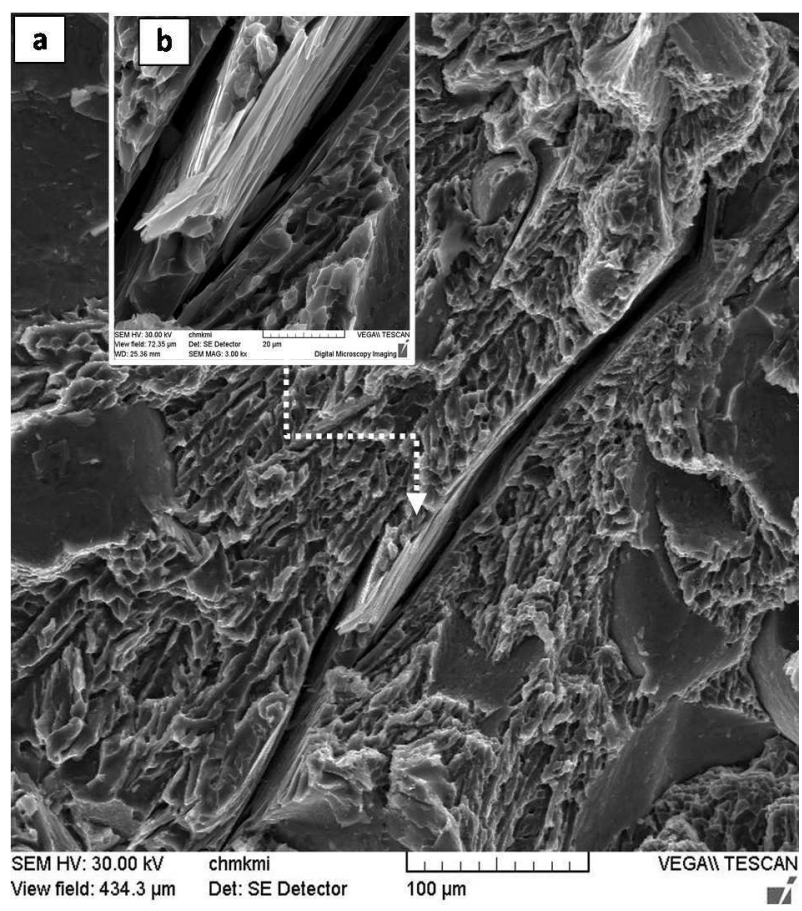

Fig. 7 Fracture surface in alloy with $0.559 \% \mathrm{Fe}$ : a) transcrystalline ductile fracture with interfacial fracture and fine cleavage; b) detail of interfacial fracture between matrix and $\mathrm{Al}_{5} \mathrm{FeSi}$ phase, SEM

It can be seen that the fracture surfaces in alloy B with a higher iron content exhibit many smooth flat areas separated by tearing ridges (Fig. 6 and Fig. 7). These ridges are the most common morphology in quasi-cleavage fractures. They are usually considered to be interactions between cleavage cracks and crystal grains with plastic deformation. The shape of tear ridges depends on the orientation of Fe-phases on fracture surface. For the experimental alloys, the existence of tearing ridges indicates that a certain amount of micro-porosities or micro-cracks pre-existed in the matrix and these defects link with each other by necking the matrix during the tensile process. We can see typical river line patterns on the surface of the Fephase (Fig. 6b), which is the most characteristic for fracture surface of brittle material.

The $\mathrm{Al}_{5} \mathrm{FeSi}$ phase has strength and plastic properties different from those of the $\alpha$-matrix. In the case of a load, it causes a concentration of tension in its surroundings, the matrix deforms plastically, and we can observe the sointerfacial fracture (fracture at the boundary between the $\alpha$-matrix and the brittle Fe-intermetallic phase - Fig. 7b).

Fracture of $\mathrm{Al}_{5} \mathrm{FeSi}$ phase is documented in Fig. 8. Fragmentation of $\mathrm{Al}_{5} \mathrm{FeSi}$ phase during crack initiation, followed by cleavage, is shown by high magnification.

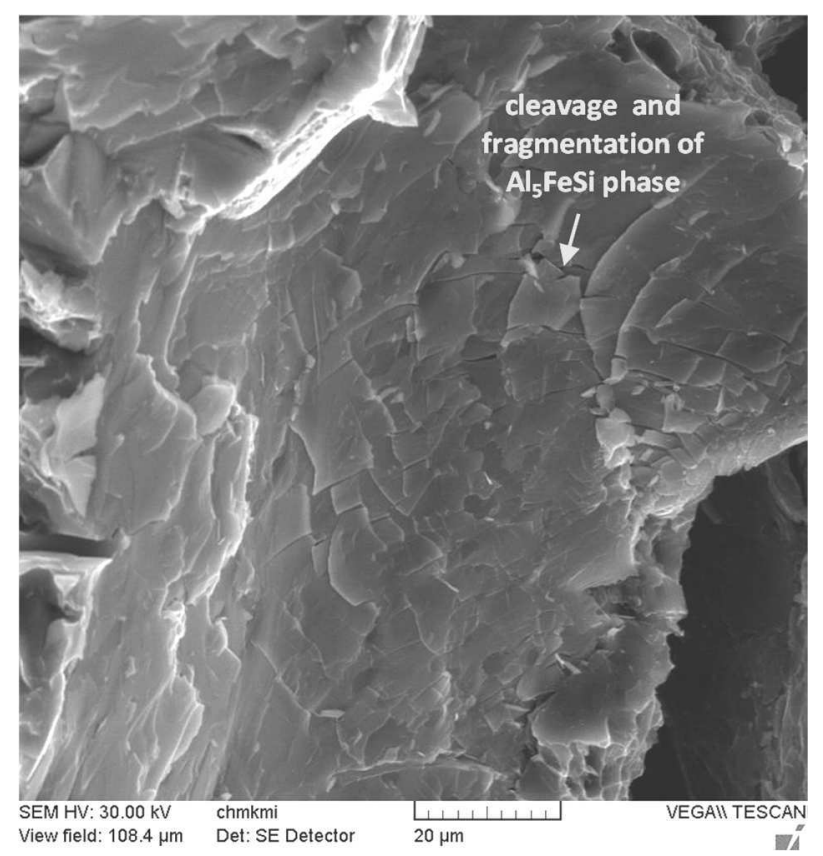

Fig. 8 Fragmentation of $\mathrm{Al}_{5} \mathrm{FeSi}$ phase during crack initiation, folloved by cleavage, SEM

\section{Conclusions}

The effect of Fe-intermetallic phases $\left(\mathrm{Al}_{5} \mathrm{FeSi}\right)$ on microstructure, mechanical properties and fracture surfaces of new self-hardening AlZn10Si8Mg alloy (made from secondary recycled aluminium) with $0.150 \% \mathrm{Fe}$ and $0.559 \%$ Fe was analyzed. On the basis of the experimental results, the following conclusions can be stated:

The microstructures of the recycled (secondary) alloys AlZn10Si8Mg with different content of Fe (alloy A $-0.150 \% \mathrm{Fe}$ and alloy B $-0.559 \% \mathrm{Fe}$ ) are the same and consist of $\alpha$-phase, eutectic and variously types of intermetallic phases (Chinese script - $\mathrm{Mg}_{2} \mathrm{Si}$, Fe-needles $\mathrm{Al}_{5} \mathrm{FeSi}$ and ternary eutectic $\mathrm{Al}-\mathrm{MgZn}_{2}-\mathrm{Cu}$ ). Eutectic $\mathrm{Si}$ morphology has the same shape - fine bars, that grow from one nucleation place but Si bars in alloy B are finer, 
probably because of the faster cooling rate;

SDAS factor, which represent an effect of cooling rate with increasing the $\mathrm{Fe}$ content, is lower;

The size of needle-like $\mathrm{Al}_{5} \mathrm{FeSi}$ phases and their distribution are greatly affected by the amount of iron. With the increasing content of Fe from $0.150 \%$ to $0.559 \%$, the area proportion of $\mathrm{Al}_{5} \mathrm{FeSi}$ phases increased from $0.9 \%$ to $2.15 \%$; the average length of needles increased from $20.98 \mu \mathrm{m}$ (locally it is $70 \mu \mathrm{m}$ ) to $27.71 \mu \mathrm{m}$ (locally it is $109 \mu \mathrm{m})$;

Mechanical properties slightly decreased with the increasing content of Fe, YTS from $185 \mathrm{MPa}$ to $176 \mathrm{MPa}$; UTS from $187 \mathrm{MPa}$ to $178 \mathrm{MPa}$; Brinell hardness increased; ductility does not change;

The fracture surfaces of alloys A and B consist of transcrystalline ductile fracture, in alloy A the transcrytalline ductile fracture in the eutectic and on the $\alpha$-matrix is dominant and the transcrystalline cleavage fracture was observed not much, while in alloy B the transcrystalline cleavage fracture is dominant, because of the presence of a larger number of hard and brittle Fe-phases $\left(\mathrm{Al}_{5} \mathrm{FeSi}\right)$.

\section{Acknowledgement}

This study has been supported by the Scientific Grant Agency of the Ministry of Education of the Slovak Republic VEGA 01/0533/15 and KEGA 049ŽU-4/2017. The authors would like to thank Mrs. Anna Macúchová for preparation of metallographic samples.

\section{References}

[1] https://www.european-aluminium.eu/resourcehub/aluminium-automotive-manual/

[2] DAS, S. K., GREN, J. A. S. (2010). Aluminum Industry and Climate Change-Assessment and responses. In: JOM - the journal of the Minerals, Metals and Materials Society, Vol. 62, No. 2, pp. 27-31.

[3] SCHLESINGER, M. E. (2013). Aluminum Recycling. 2nd ed. CRC Press, Boca Raton, Florida, USA.

[4] McMillan, C. A., SKERLOS, S. J., KEOLEIAN, G. A. (2012). Evaluation of the Metals Industry's Position on Recycling and its Implications for Environmental Emissions. In: Journal of Industrial Ecology, Vol. 16, No. 3, pp. 324-333.

[5] KUCHARIKOVÁ, L., TILLOVÁ, E., BOKUீVKA, O. (2016). Recycling and properties of recycled aluminium alloys used in the transportation industry. In: Transport problems, Vol. 11, No. 2, pp. 117-122.

[6] TILlOVÁ, E., CHALUPOVÁ, M., HURTALOVÁ, L., ĎURINÍKOVÁ, E. (2011). Quality control of microstructure in recycled AlSi cast alloys. In: Manufacturing Technology, Vol. 11, No. 11, pp.70-76.
[7] TAYLOR, J. A. (2012). Iron-containing intermetallic phases in Al-Si based casting alloys. In: Procedia Materials Science, 1, pp. 19-33.

[8] SAMUEL, E., SAMUEL, A. M., DOTY, H. V. et all. 2014. Intermetallic phases in Al-Si based cast alloys: new perspective. In: International Journal of Cast Metals Research, Vol. 27, No. 2, pp. 107114.

[9] SHABSESTARI, S. G. (2004). The effect of iron and manganese on the formation of intermetallic compounds in aluminum-silicon alloys. In: Materials Science and Engineering A, Vol. 383, No. 2, pp. 289-298.

[10] SAMUEL, A. M., DOTY, H. W., VALTIERRA, S. et all. (2018). Beta Al5FeSi phase platelets-porosity formation relationship in A319.2 type alloys. In: International Journal of Metalcasting, Vol. 12, No.1, pp. 55-70.

[11] LI, Z., LIMODIN, N., TANDJAOUI, A., QUAEGEBEUR, P., WITZ, J.F., BALLOY, D. (2017). Influence of Fe content on the damage mechanism in A319 aluminum alloy: Tensile tests and digital image correlation. In. Engineering Fracture Mechanics. Vol. 183, pp. 94-108.

[12] LU, L., DAHLE, A. K. (2005). Iron-Rich Intermetallic Phases and Their Role in Casting Defect Formation in Hypoeutectic Al-Si Alloys. In: $\mathrm{Me}-$ tallurgical and Materials Transactions A, Vol. 36, No. 13, pp. 819-835.

[13] MOUSTAFA M. A. (2009). Effect of iron content on the formation of $\beta$-Al5FeSi and porosity in AlSi eutectic alloys. In: Journal of Materials Processing Technology. Vol. 209, No. 1, pp. 605-610.

[14] BOROMEI, L. CESCHINI, L., MORRI, A., NICOLETTO, G., RIVA, E. (2010). Influence of the solidification microstructure and porosity on the fatigue strength of Al-Si-Mg casting alloys. In: Mettalurgical Science and Technology, Vol. 28, No.2, pp. 18-24.

[15] CESCHINI, L., BOROMEI, I., MORRI, A., SEIFEDDINE, S., SVENSSON, I. L. (2009). Microstructure, tensile and fatigue properties of the $\mathrm{Al}-10 \% \mathrm{Si}-2 \% \mathrm{Cu}$ alloy with different $\mathrm{Fe}$ and Mn content cast under controlled conditions. In: Journal of Materials Processing Technology, Vol. 209, No. 15-16, pp. 5669-5679.

[16] HURTALOVÁ L., TILLOVÁ E., CHALUPOVÁ M., BELAN J., UHRÍČIK M. (2016). The Influence of Two Different Casting Moulds on the Fatigue Properties of the Al-Si-Cu Cast Alloy. In: Öchsner A., Altenbach H. (eds) Machining, Joining and Modifications of Advanced Materials. Advanced Structured Materials, vol 61. Springer, Singapore. 
[17] TILlOVÁ E., CHALUPOVÁ, M., HURTALOVÁ, L. (2010). Evolution of the Ferich phases in recycled AlSi9Cu3 cast alloy during solution treatment. In: Communications - Scientific letters of the University of Žilina, Vol. 12, No. 4, pp. 95-101.

[18] BOLIBRUCHOVÁ, D., ŽIHALOVÁ, M. (2013). Possibilities of iron elimination in aluminium alloys by vanadium. In: Manufacturing Technology, Vol. 13, No. 3, pp. 289-296.

[19] BORKO, K., TIllovÁ, E., CHALupOVÁ, M. (2016). The impact of Sr content on Fe-intermetallic phase's morphology changes in alloy AlSil0MgMn. In. Manufacturing Technology, Vol. 16, No. 1, pp. 20-26.

[20] BOLIBRUCHOVÁ, D., RICHTÁRECH, L., DOBOSZ, S. M., MAJOR-GABRYS, K. (2017). Utilisation of mould temperature change in eliminating the $\mathrm{Al} 5 \mathrm{FeSi}$ phases in secondary A1Si7Mg0.3 alloy. In: Archives of Metallurgy and Materials, Vol. 62, No. 1, pp. 339-344.

[21] HURTAlOVÁ, L., TILlOVÁ, E. (2013). Elimination of the negative effect of Fe-rich intermetallic phases in secondary (recycled) aluminium cast alloy. In: Manufacturing technology, Vol. 13, No. 1, p. 44-50.
[22] CAStella, C., PETER, I., LOMBARDO, S., ROSSO, M., MOLINA, R. (2018). Self-hardening aluminum alloys and their potential applications in the automotive industry. In: Metalllurgia Italiana, 5, pp. 19-30.

[23] ROSSO, M., PETER, I., CASTEllA, C., MOLINA, R. (2015). Optimization of composition for self-hardening AlZn10Si8Mg alloys. In: Materials Today: Proceedings, Vol. 2, No. 10, pp. 4949-4956.

[24] GARIBOLDI, E., LEMKE, J. N., ROVATTI, L., BAER, O., TIMELLI, G., BONOLLO, F. (2018). High-temperature behavior of high-pressure diecast alloys based on the Al-Si-Cu system: The role played by chemical composition. In: Metals. Vol. 8, No. 5, 348.

[25] SHANKAR, S., RIDDLE, Y.W., MAKHLOUF, M. M. (2004). Nucleation Mechanism of the Eutectic Phases in Aluminum-Silicon Hypoeutectic Alloys. In: Acta Materialia, Vol. 52, No. 15, pp. 4447-4460.

[26] SHANKAR, S., MAKHLOUF, M. M. (2006). Authors' Reply to Reply of Discussion on Nucleation Mechanism of Eutectic Phases in Aluminum-Silicon Hypoeutectic Alloys. In. Metallurgical and Materials Transactions A, Vol. 37A, No. 4, pp. 1353-1356. 